\title{
Record of living individual of the freshwater snail Gyraulus ross- maessleri (Auerswald, 1852) in Slovakia after thirty-eight years (Gastropoda: Planorbidae)
}

\author{
TOMÁŠ ČEJKA ${ }^{1}$, EVA BULÁNKOVÁ ${ }^{2}$, JOZEF HALGOŠ² \& STANISLAVA BAČíKOVÁ $^{3}$ \\ ${ }^{1}$ Institute of Zoology, Slovak Academy of Sciences, Dúbravská cesta 9, SK-84206 Bratislava, Slovakia; e-mail: cejka@savba.sk \\ ${ }^{2}$ Faculty of Natural Sciences, Comenius University, Department of Ecology, Mlynská dolina, SK-84215 Bratislava, Slovakia; e-mail: \\ bulankova@fns.uniba.sk \\ ${ }^{3}$ Department of Surface Water Quantity and Quality, Slovak Hydrometeorological Institute, Jeséniova 17, SK-83315 Bratislava; e-mail: \\ stanislava.bacikova@shmu.sk
}

\begin{abstract}
Č́̇JKa T., BulánKová E., Halgoš J., BAČíková S., 2005: Record of living individual of the freshwater snail Gyraulus rossmaessleri (Auerswald, 1852) in Slovakia after thirty-eight years (Gastropoda: Planorbidae). - Malacologica Bohemoslovaca, 4: 1-2. Online serial at $<$ http://mollusca.sav.sk $>20$-May2005 .

A living adult and two fresh shells of the freshwater snail Gyraulus rossmaessleri (Auerswald, 1852) (Gastropoda, Planorbidae) were found in the lower Morava River alluvial plain in SW Slovakia after thirty-eight years.
\end{abstract}

The shell of Gyraulus rossmaessleri is small- to medium sized, usually not exceeding $4 \mathrm{~mm}$ in diameter and $1.3 \mathrm{~mm}$ in height. It is similar to Gyraulus laevis (Alder, 1838) in shape, but umbilicus and sutires are shallower; the whorls are rounded, never angled or keeled. The aperture has a characteristic thickened lip (that does not necessarily terminate growth). Growth marks indicating growth interruptions are regularly present (desiccation of habitat). The surface is not smooth, but rather dull, with a very fine reticulate sculpture (spiral striae very close to each other). The colour is reddish brown (MEIER-BROOK 1983).

Locality and material examined: SW Slovakia, $4 \mathrm{~km}$ W from village of Závod (48³2'47” N, 16 ${ }^{\circ} 57^{\prime} 52$ ” E) (grid reference databank of Fauna of Slovakia DFS $7468 \mathrm{c}$ ), temporary pool in forest fragment of the noninundated area behind the dam, gravel-sandy bottom covered with mud and thick layer of poplar and ash leaves (Fig. 1), $149.0 \mathrm{~m}$ a.s.1., 8 October, 2001, E. Bulánková and J. Halgoš leg., one living adult and two fresh shells found. The material was not dissected, identified only by shell morphology. T. Čejka det. et coll., M. Horsák rev.

Distribution: Gyraulus rossmaessleri is an European species with very restricted central European range. Its more or less continuous occurrence is known from $\mathrm{S}$, W, central and eastern Europe: Germany (MEIERBROOK 1983; GLÖER 2002), Austria (FALKNER 1995), Czech Republic (JUŘIČKOVÁ et al. 2001), Slovakia (LUČIVJANSKÁ \& ŠTEFFEK 1991), Switzerland (TURNER et al. 1998), Poland (PIECHOCKI 1979), Hungary (RICHNOVSZKY \& PINTÉR 1979); according to SCHLESCH (1942) in Lithuania as well.

LISICKÝ (1991) did not mention the species in the monograph of Slovak molluscs; few records were discovered by LUČIVJANSKÁ \& ŠTEFFEK (1991) in collection of T. Weisz from 1960s (the latest record came from 1963, village of Senné, East Slovakia). ČEJKA (2000) found 3 fresh empty shells in the flood debris of the Danube River in the Bratislava City.

\section{Acknowledgements}

This work was partly supported by VEGA Grants No. 1/1291/04 and $2 / 5014 / 25$.

\section{References}

ČEJKA T., 2000: Analýza náplavov Dunaja pri Bratislave v oblasti slovensko-rakúskej hranice z malakozoologického hl'adiska [Malacozoological analysis of the wood debris deposited by the Danube River in the area of Slovak-Austrian border]. - Folia faunistica Slovaca, 5: 73-80. 
FALKNER G.,1995: Gyraulus (Lamorbis) rossmaessleri (Auerswald, 1852) in Österreich (Gastropoda: Planorbidae). - Nachr.bl. erste Vorarlb. malakol. Ges., 3: 8-11.

JuřičKOVÁ L., HosÁK M. \& BERAN L., 2001: Checklist of the molluscs (Mollusca) of the Czech Republic. - Acta Soc. Zool. Bohem., 65: 25-40.

MeIER-Brook C., 1983: Taxonomic studies on $G y$ raulus (Gastropoda: Planorbidae). - Malacologia, 24 (1-2): 1-113.

GLÖER P., 2002: Süsswassergastropoden Nord- und Mitteleuropas. - ConchBooks, Hackenheim, 327 pp.

LISICKÝ M. J., 1991: Mollusca Slovenska [Mollusca of Slovakia]. - Veda, Bratislava, 344 pp.

LUČIVJANSKÁ V. \& ŠTEFFEK J., 1991: Malakozoologická zbierka MgPh. Tibora Weisza a jej význam pre slovenskú malakozoológiu I. [Mala- cozoological collection of Dr Tibor Weisz and its importance fot the Slovak malacozoology]. - Zbor. Slov. nár. Múz., Prír. Vedy, 37: 55-83.

PIECHOCKI A., 1979: Mięczaki (Mollusca): Ślimaki

(Gastropoda) [Molluscs: Gastropods]. - Fauna

Sładkowodna Polski, Warszawa, 187 pp.

RichNOVSZKY A. \& PINTÉR L., 1979: A vízicsigák és kagylók (Mollusca) kishatározója [Identification of the freshwater Mollusca] - Vízügyi Hidrobiológia, 6: 1-206.

SCHLESCH H., 1943: Die Land- und Süsswassermollusken Lettlands mit Berücksichtigung der in den Nachbargebieten vorkommenden Arten. - Korr. naturf. Ver. Riga, 64 [1942]: 246-360.

Turner H., Kuiper J.G., TheW N., Bernasconi R., RÜETSCHI J., WÜthrich M., Gosteli M., 1998: Atlas der Mollusken der Schweiz und Liechtensteins. Fauna Helvetica 2. - Neuchâtel, 527 pp.

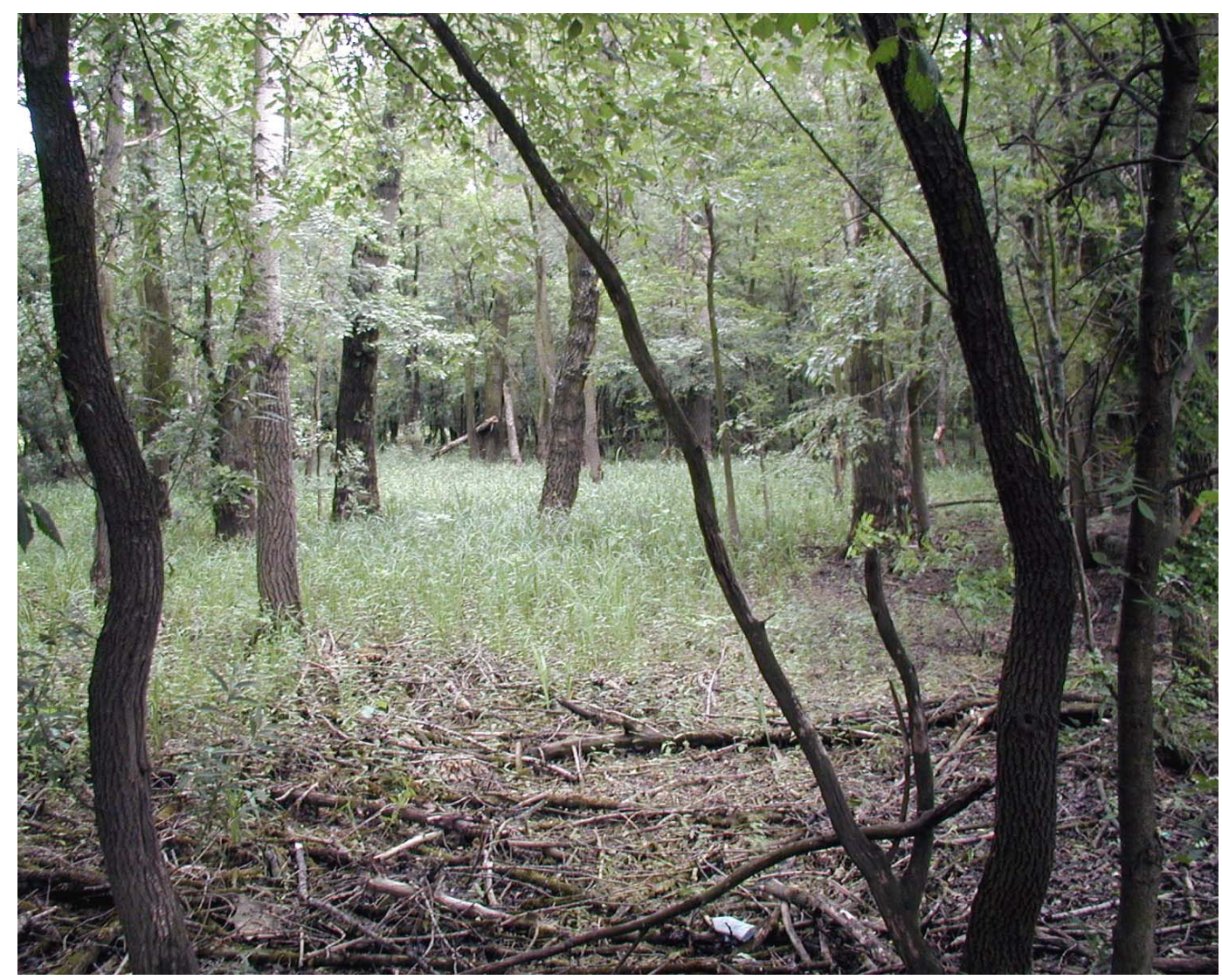

Fig. 1. The habitat of the freshwater snail Gyraulus rossmaessleri in the dried-up stage (SW Slovakia, the lower Morava River) 